\title{
Review of Measures taken by the Government and the Banking Regulator for Successful Transition to a Financially Inclusive Economy: An Empirical Study of India
}

\author{
Reena Agrawal $^{1 *}$ \\ 1 Jaipuria Institute of Management, Finance \& Accounting and Entrepreneurship, Vineet Khand, Gomti \\ Nagar, Lucknow India
}

\begin{abstract}
The current study was done to evaluate the measures used by the Government of India and Indian Banking Regulator -Reserve Bank of India to promote financial inclusion in India. The study aimed at reviewing the impact of the initiatives on financial inclusion. The paper also intended to explore the impact of increasing penetration of mobile phone and internet on financial inclusion. The study revealed that government initiatives like Pradhan Mantri Jan Dhan Yojana (PMJDY), Aadhar Enabled Payment Systems (AEPS) and Direct Benefits Transfer; regulatory reforms by Reserve Bank of India such as Immediate Payment Service (IMPS), Prepaid Payment Instruments, differentiated banks; digital revolution and active participation of private technology companies, are facilitating in successful transition into a financially inclusive economy.
\end{abstract}

Key words: financial inclusion, mobile money, digital financial inclusion, branchless banks

JEL Classification: E425, P34

\section{INTRODUCTION}

"Financial inclusion is crucial in decreasing poverty and attaining inclusive economic growth. Financial inclusion is not an end, but a means to an end [...]. Greater access to financial services may help decrease income inequality and accelerate economic growth". (Demirguc-Kunt et al., 2015).

Availability of funds, especially for the deprived and the underprivileged, is a powerful intervention for economic development. As leaders and policy-makers search for feasible solutions for balanced and sustainable growth, equitable access the financial product and services, reduction in disparity and poverty come out to be inevitable desirables in the process. Conducting financial literacy programs and intensifying the use of financial services, helps in consolidating domestic savings, boosts financial sector resilience, stimulates business, opens up a new horizon for deprived groups and fosters inclusive growth. An inclusive and efficient financial system also helps the government to proficiently implement societal strategies (GPFI, 2014a) and extend new economic opportunities to the people living at low strata of the society. Financial inclusion is likely to unleash the immensely unexploited prospective at the grass root level of India`s economy. Possibly, financial inclusiveness can result in a revolution of prosperity and growth.

\footnotetext{
*E-mail: reena.agarwal@jaipuria.ac.in
} 
In India, for decades, banks were responsible for financial inclusion. But the fact of reality is that financial inclusion can be achieved only when there is strong political will, administrative backing and dogged persuasion by the financial regulator. Dovetailing monetary policies with the ongoing structural reforms, with the government as a fulcrum, can lead to steady and sustainable financial inclusion. In the recent years both state and the Reserve Bank of India have numerous pioneering and devoted measures to push the agenda of financial inclusion. At present, the Indian economy is moving through a phase of extreme transformation due to globalisation and technological advancement. The increasing penetration of mobile phone and internet, entry of technology companies in the financial arena and disruptive innovations along with policy and regulatory reforms have improved the financial outreach in the country.

The current study was done to evaluate the measures taken by the state and the banking regulator to promote financial inclusion in India. The intention also was to study the impact of these measures in promoting financial inclusion in the country. The paper also intended to explore the impact of increasing penetration of mobile phone and internet on financial inclusion in the banking sector. The study sought answers for the following questions:

1. What role did banks and India Post play to promote financial inclusion?

2. What are the steps taken by the state to support financial inclusion and what has been the impact?

3. What are the measures taken by the banking regulator to stimulate financial inclusion and what has been the impact?

4. What is the impact of increasing penetration of mobile phone and internet on financial inclusion?

This was empirical research. The research was built on secondary sources of information. The facts and figures were collected and put together from large number of publically available sources such as periodicals, research papers, reports and bulletins by the Indian Banking Regulator- Reserve Bank of India (RBI), World Bank, government documents such as report on Financial Sector Reform by Planning Commission, newspaper articles, research reports by private agencies such as KPMG , PWC, ASSOCHAM etc.

The study provides valuable insights to the traditional banks and microfinance institutions to help them to envision policies to profit from the ongoing changes in India's economy and also advantage from globalisation. The research will stimulate the policy-maker to bring further progressive reforms to stimulate financial outreach to the bottom of the pyramid through digital podia, without jeopardising their interest. The research would provide insights to the researchers and academicians, who can explore further, to examine the effects of digitisation on the persons at the grass root level and evaluate whether there is any correlation between digitisation and poverty reduction, financial inclusion and poverty reduction and other such aspects.

\section{OVERVIEW OF THE LITERATURE}

\section{Financial inclusion}

Financial inclusion is "widespread availability of a wide variety of financial services at a rational cost. These comprise banking, insurance and equity" (Planning Commission, 2009). GOI (2008) defines financial inclusion as the procedure of ensuring access to financial services to susceptible groups at a reasonable cost. According to Chakraborty (2011), financial inclusion is "ensuring access to suitable financial products and services needed by all present in society especially the deprived groups at a reasonable cost, in transparent manner financial institutions". Most definitions of financial inclusion talk about -access to financial services, thus referring to the supply side of financial services. This means that merely by giving the right to use financial services, the deprived groups will start using the services, regardless of whether 
they are familiar with the services, they need it, or the services suitable to them. However, financial inclusion invariably includes both the demand and the supply side of financial services.

\section{Roadblocks in financial inclusion}

Gangopadhayay (2009) found that a large number of the low-income adult population in India is financially excluded - they include not merely those who live in rural areas but also those reside in urban areas. According to Ravichandran and Alkhathlan (2009), on the demand side illiteracy, low income levels, lack of consciousness and knowledge of financial products and social exclusion are the key hurdles in financial inclusion in India. While on insufficient branches, arrogance of bank officials, lengthy paperwork, lack of customized products and linguistic barriers are the major obstacles on the supply side. Das (2010) suggested that banks need to adopt new approaches, such as mobile-banks, agency system instead of relying on selfhelp groups, to reach vast populations living in remote areas and emphasized on the need to scale up the technology to build a desirable inclusive financial ecosystem. Chakraborty (2009) focused on the role of technology in financial inclusion, and said banks should use technology platform, however, the technology solution should be user-friendly.

\section{Role of technology in enhancing financial inclusion}

According to Hishigsuren, (2006) technology can help banks to operate thru mobile, ATMs and point-of-sale (PoS) grids etc., it thus helps in improved outreach, quicker processing, reduced operational costs and increased customer satisfaction. Technology is a tactical instrument which facilitates operators to become effective and proficient. It serves the twin purpose - outreach to deprived groups and sustainability (Brynjolfsson and Hitt, 2000). MFIs in Bolivia, Peru used ATMs, smart cards and voice prompts, to enlarge microfinance nets in remote areas with a large number of illiterate people. These service reduced operating costs and benefits were passed to the users (Hernandez and Mugica, 2003; Global Envision, 2003). In Uganda, MFIs used MIS, personal digital assistants (PDAs), ATMs, mobiles and smart cards (Ssewanyana, 2008). MIS for microfinance services, efficiently process transactions, offer quality services to customers, and improves the reach (Turaga, 2004). PDAs are small palmtops that allows credit officers to get connected to their institution's MIS from the areas where they operate (Turaga, 2004). MFIs operating in African nations, also use technology for improved efficacy and quicker progress (Kinyanjui, 2009).

\section{Role of telecom companies in boosting financial inclusion}

In East Africa, telecom companies render services like receipt and disbursement national and international payments. Safaricom, one such telecom company, single-handedly helps above seven million customers with an agent-net which surpasses the entire bank branches in Kenya. In Kenya, the agent-based M-Pesa provides mobile-enabled, P2P money transfer system, it also allows users to store money in electronic account and withdraw and deposit money at M-Pesa's agent locations (Hughes and Lonie, 2007; Morawczynski and Pickens 2009; Morawczynski, 2008; Morawczynski, 2009; Mas and Morawczynski, 2009). Though M-Pesa wasn't the first to operate, yet its rapid acceptance among the people is what discriminates it from G-Cash or Smart Money or in Philippines (Mendes and Alampay, 2007; Wishart, 2006). An M-Pesa-linked bank account is popular among the public, as the clients can open bank accounts using their M-Pesa wallets, get loans without any paperwork and get interest income on savings. The same was imitated in Tanzania, Afghanistan, and Pakistan CGAP (2016). Globe Telecom, in the Philippines, offer an e-wallet facility to its clients, even non-subscribers can use the services. In the Philippines, above two million people use mobile wallets for receipts and disbursements. (Wishart, 2006; Mendes and Alampay, 2007).

In the Philippines, Smart offered BayaLoad, is used for state transfers, national health insurance program, national housing agency and social benefits schemes, (Shrader, 2013). It allows users P2P transfers, paying utility bills, pay at retail stores (Murphy, 2014). SmartMoney in oona in Zambia and Tanzania enabled mobile disbursements between farmers and suppliers, 
resulting in lowering operating costs and enhanced security (Parada and Bull, 2014). Zoona, which works in Malawi and Zambia, provides farmers to generate electronic vouchers and use ewallets (Pénicaud and Katakam, 2014). M-KOPA in Kenya and Mobisol in Tanzania provide digital payment option (Parada and Bull, 2014).

Mobile point-of-sale (mPOS) enables minor traders to use mobile as POS-terminals as a substitute to cash transactions. The global mPOS installed base is anticipated to increase from 13.3 million units today to 54.0 million units in 2019, with maximum growth in developing nations (Rolfe, 2015). Payment kiosks are particularly widespread in Eastern Europe, Russia and Central Asia and, they are increasing in India, China, Malaysia, Brazil, Jordan, Argentina, Peru, Chile, Colombia and Panama. They are popular among migrant labourers for transnational transmittals (Kravtsov, 2013; Owens, 2015; PPI, 2014). Digital payment services like M-Pesa, Tigo Pesa, Airtel Money, Easypaisa, B - Kash, help in promoting financial inclusion as they process repetitive, small-value high volume transactions remotely and provide a variety of financial services, at near marginal cost.

Mobile banking has also facilitated government-to-person (G2P) payments. It brings the formerly un-served, in the ambit of organized financial services, by channelising the steady flow of money into their accounts. In South Africa over 80 per cent and in Brazil 88 per cent of the payees get state remittance in their bank accounts. Move to digital G2P payments has helped Mexico to cut it's expenditure on pensions, wages and other social benefits by 3 per cent per annum (Demirguc-Kunt et al. 2015). Thus digitizing G2P disbursements have momentous effects on the overall economy of the country in terms of efficacy, security and fair approach.

\section{FINDINGS}

\section{Banks}

Around the world, the most usual mode of savings is thru bank account, India being no exception. Yet, with above 1.3 billion population, only $52.8 \%$ of adults have bank accounts. India is home to $21 \%$ of the world's unbanked adults (World Bank, 2015). As India toils hard to promote financial inclusion, plotting various financial access points at different levels will help to shift more people from unbanked to banked.

The level of financial inclusion in a country is usually measured on the basis of three tangible dimensions: I. Branch Penetration; II. Deposit Penetration III. Credit Penetration. According to the Reserve Bank of India`s report on Financial Inclusion Progress: Banks and RRBS during 2014-15:

I. Branch Penetration: There were 33,378 banking outlets in villages in 2010, which increased to 46,126 (2014) and 49,571 (2015). In 2010 there were 34,316 banking outlets in villages which were working on branchless mode, which increased to 337,678 (2014) and 504,142 (2015). In 2010 there were 67,694 total banking outlets in villages, while in 2014 they increased to 383,804 and 553,713 in 2015. The urban locations covered through BCs were 447 in 2010, 60730 in 2014 and 96,847 in 2015. 


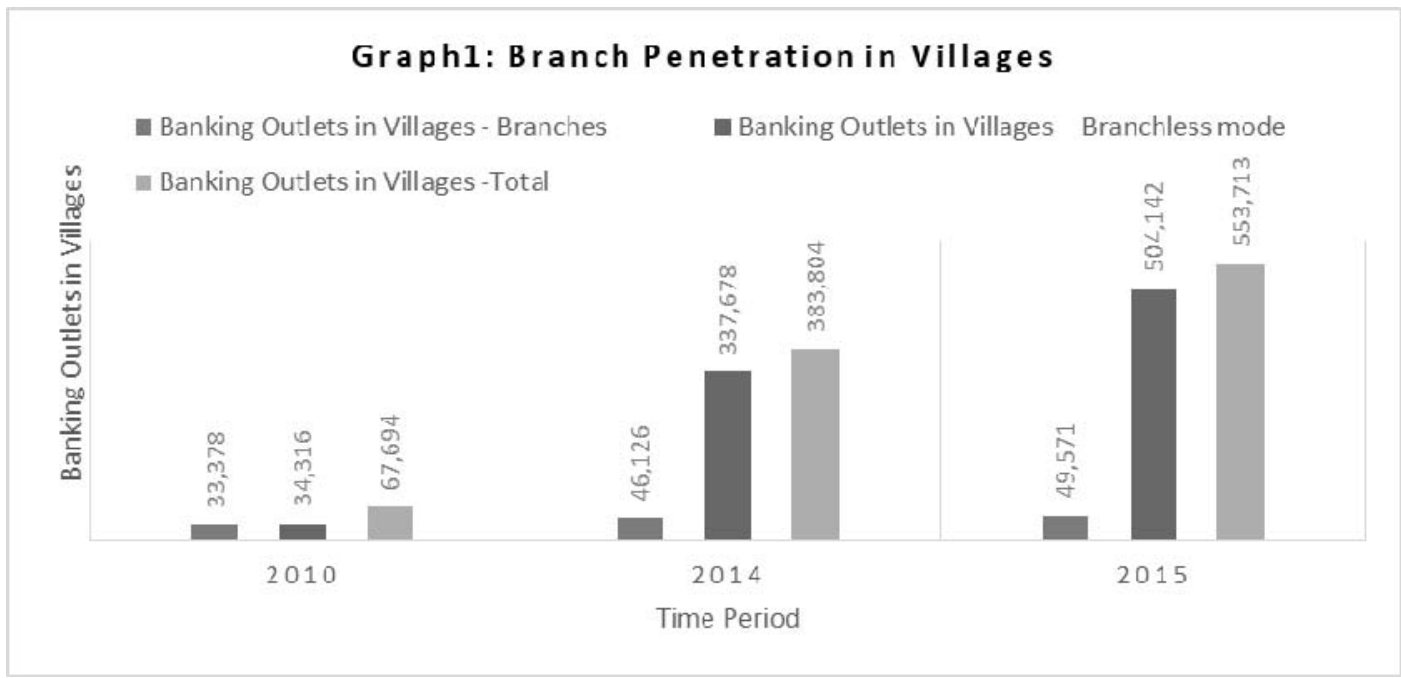

Source: RBI, Financial Inclusion Plan-Summary Progress of All Banks Including RRBs 2014-15

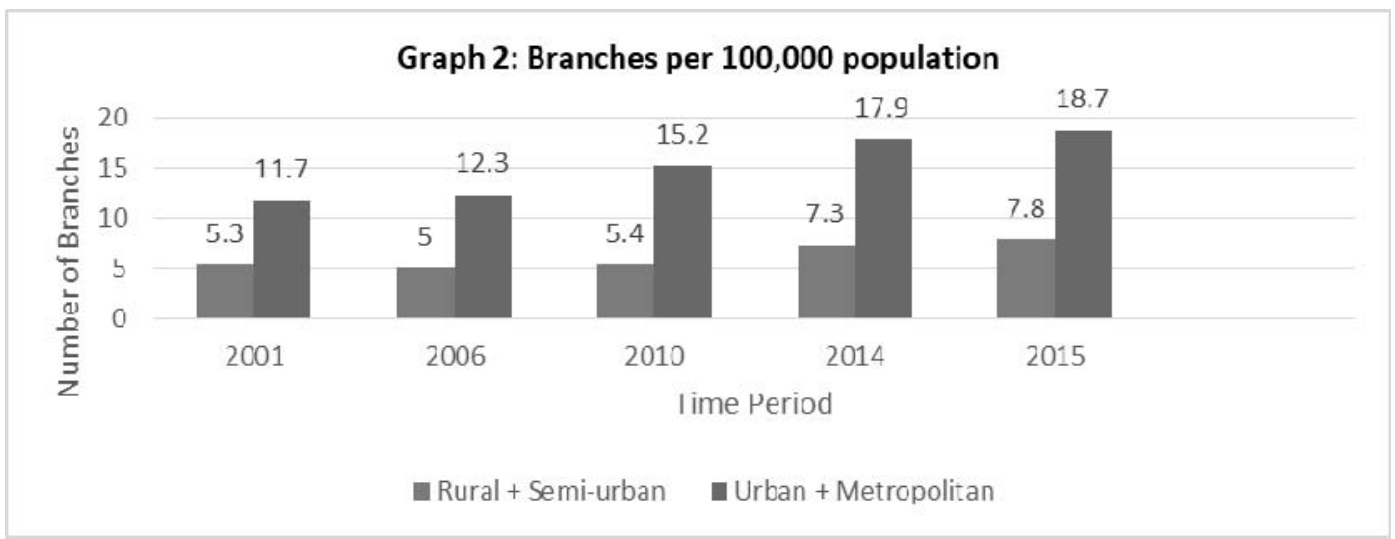

Source: RBI, Report of the Committee on Medium-term Path on Financial Inclusion 2015

The above graph clearly brings out that though there is substantial surge in the penetration of banks in the villages, yet the number in case of remote areas is 7.8 per 100,000 population, while in urban and metropolitan areas it is 18.7 per 100,000 population which continues to be substantially low when compared to other growing economies.

II. Deposit Penetration: The deposits in Basic Savings Accounts thru branches amounted to INR 44.3 billion in 2010, INR 273.3 billion in 2014 and INR 365.0 billion in 2015. The deposits in Basic Savings Accounts thru BCs amounted to INR 10.7 billion in 2010, INR 39.0 billion in 2014 and INR 74.6 billion in 2015. Total deposits in Basic Savings Bank Deposit Accounts amounted to INR 55.0 billion in 2010, INR 312.3 billion in 2014 and INR 439.5 in 2015. 


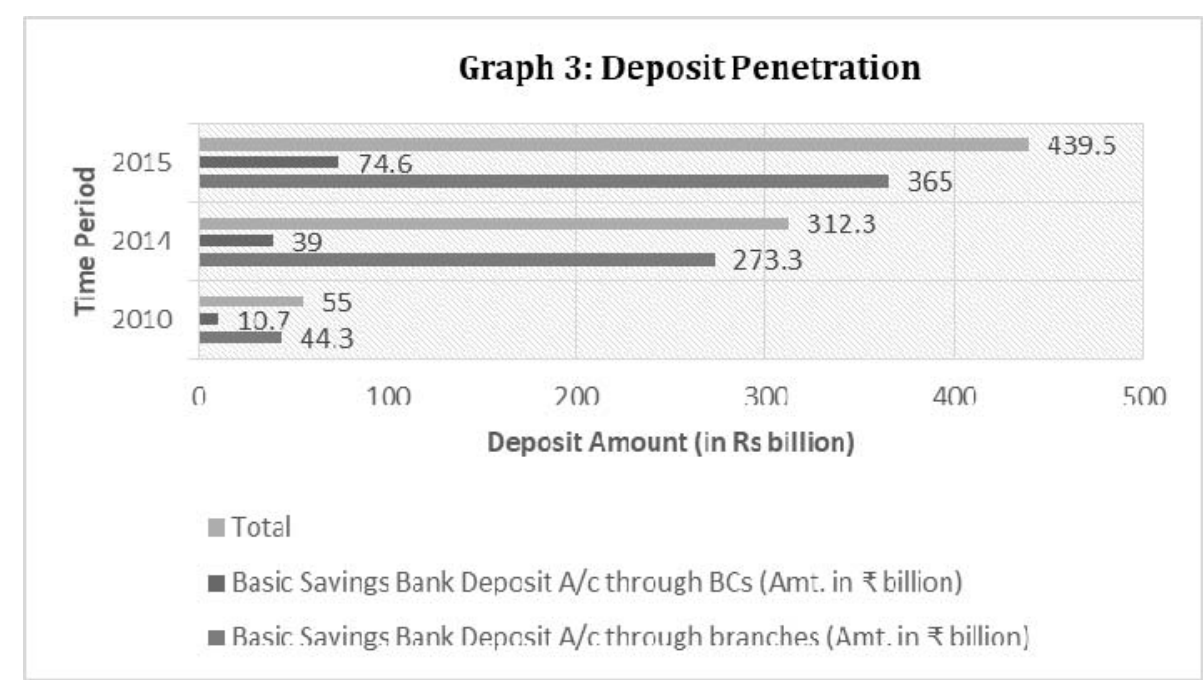

Source: RBI, Financial Inclusion Plan-Summary Progress of All Banks Including RRBs 2014-15

III. Credit Penetration: Overdraft facility availed in Basic Savings Accounts amounted to INR 0.1 billion in 2010, which increased to INR 16 billion in 2014 and to INR 19.9 billion in 2015. Kisan Credit Card transactions amounted to INR 1,240.1 billion in 2010, which increased to INR 3,684.5 billion in 2014 and to INR 4,382.3 in 2015. General Credit Card transactions amounted to INR 35.1 billion in 2010; it increased to INR 1,096.9 billion in 2014 and to INR 1,301.6 in 2015.

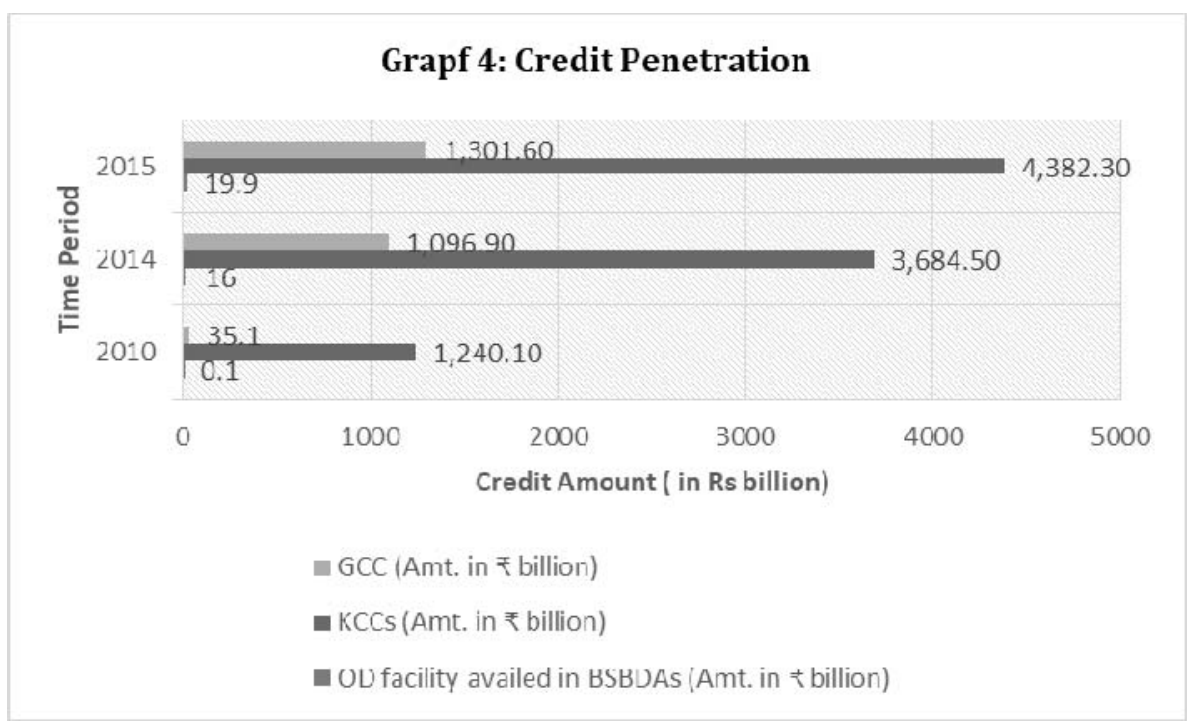

Source: RBI, Financial Inclusion Plan-Summary Progress of All Banks Including RRBs 2014-15

Mentioned below are some of the select measure taken by some of the banks in India to boost financial inclusion in the country:

i. Axis Bank: Facilitates the opening of bank account using the e-KYC route.

ii. Bank of Baroda: established above 1,000 urban kiosks and provided banking services through mobile vans in six states.

iii. Canara Bank: Introduced Micro Pension and Micro Insurance schemes and conducts credit counselling.

iv. Dena Bank: Installed biometric ATMs for illiterate and semi-literate clients. 
v. HDFC Bank: Created a net of remote trade hubs to reach the financial excluded.

vi. ICICI Bank: Started 'Branch on Wheels' to serve remote unbanked areas. Tie-up with Mobile network operators to facilitates remittance to migrant workers.

vii. UCO Bank: Mobile vans with CBS connection are operated in unbanked areas.

viii. YES Bank: Introduced Yes Money and Micro ATMs for domestic transfers.

Source: Annual reports 2013-14 of various banks.

\section{India Post}

India Post, the state-run postal system, has provided savings products for low-income groups. In addition to financial products aimed at creating demand, India Post is a biggest postal system in the world having above 154,822 post offices - of which 1, 39,182 (89.86\%) are in remote areas (India Post 2016). As a result, the postal network exceptionally has "last mile connectivity" to contribute to financial inclusion. India Post has over 349 million accounts, serving nearly $42 \%$ of the country's adult population thru its various savings products and also served as a channel for G2P transfers under programs such as NREGA and MGNREGA. The benefits got transferred to 63 million India Post account under the above mentioned programs (India Post, 2016).

\section{Government initiatives}

Financial inclusion was a top priority of the government. Some major initiatives taken by the state to increase financial inclusion are:

a) Pradhan Mantri Jan Dhan Yojana (PMJDY): Any citizen 10 years and above in age, living below the poverty line could open a bank account with zero balance. The services offered included deposit, transfer and credit. It provided free of cost insurance cover for an accident up to Rupees One hundred Thousand, life insurance cover of INR 30,000 and RuPay debit card. The account holder could borrow loan up to INR5000. An enormous countrywide rollout of ATMs and Micro ATMs in Post Offices was proposed for the next three years. Till 2016, 132.7 million accounts in rural areas and 83.4 million accounts in urban areas were opened, and 126,000 'Bank Mitras' were appointed (PMJDY, 2015).

b) Pradhan Mantri Jan Suraksha Bima Yojana: It provides a death benefit of INR Two Hundred Thousand for a premium of INR 12 annually. Till 2016, 94.2 million Suraksha Bima Policies have been issued (PMJDY, 2015).

c) Pradhan Mantri Jeevan Jyoti Bima Yojana: It provides a renewable life insurance cover of INR Two Hundred Thousand for a premium of INR 330 per annum. As on 20 April 2016, 29.6 million Jeevan Jyoti Bima Policies have been issued (PMJDY, 2015).

d) Pradhan Mantri Mudra Yojana (PMMY): It was launched to offer loans to businesspersons at the foot of the pyramid. The target was to grant loans of INR 1.8 trillion during 201617. It intended to 'Fund the Unfunded' by giving credit starting INR 50,000 to INR 1 million, with settlement time of 5-7 years. Financial organisations reported sanctioning INR 1 trillion to above 25 million people by early 2016. The scheme is expected to advantage above 58 million micro businesses.

e) The technology-leveraged 'Aadhar' is anticipated to support widespread access and acceptance of financial products by un-served groups. Following initiatives are projected to push demand:

i. Aadhar Enabled Payment Systems (AEPS): It is Aadhar-enabled banking system that allows cash withdrawal; balance enquiry; cash deposit and funds transfer, thru PoS, micro ATM and kiosk. 
ii. Aadhar Payments Bridge System (APBS): It facilitates G2P remittances thru banks and post offices. Over 880 million 'Aadhar' cards were issued until 2015, but it aims to achieve 100 per cent coverage by 2016 (UIDAI, 2015).

iii. Direct Benefits Transfer (DBT): It enables the transfer of government benefits such as National Rural Employee Guarantee Act (NREGA), handicapped old age pension scheme, social security pension scheme, LPG subsidy etc.

iv. Creation of a viable rural banking model: It is expected to create a cost-effective model for dispensing last mile access by leveraging AEPS.

v. Analytics: 'Aadhar' data is expected to create enormous opportunity for leveraging analytics for customizing offerings.

f) 'Digital India' initiative, joined with a payments ecosystem, is laying the foundation for a digital economy. The impact of 'Digital India' initiative by 2019, as envisioned by the government, would lead to (Digital India, 2016):

i. $\quad$ Set up pan India fibre-optic grid by 2016.

ii. Providing Wi-Fi services in cities above 1 million people and key tourist spots.

iii. Providing internet access across 250,000 villages by 2019 .

iv. Make available 'digital lockers' to every citizen.

v. Develop 100 smart cities.

vi. Universal phone connectivity.

vii. Set up 400,000 internet access points.

\section{Measures taken by Reserve Bank of India (RBI)}

In a vision to encourage cashless society and ensure that the payment ecosystems are efficient, safe, accessible, inclusive and compliant with global standards Reserve Bank of India took following major initiatives (RBI, 2012):

a) Basic Savings Bank Deposit Accounts (BSBDA) scheme: It allowed people to open a bank account with zero balance (RBI, 2013). In 2010 there were 60.2 million Basic Savings Bank Deposit Account through branches, which increased to 126.0 million in 2014 and to 210.3 million in 2015. In 2010 there were 13.3 million Basic Savings Bank Deposit Accounts through BCs, which increased to 116.9 million in 2014 and to 187.8 million in 2015. Total Basic Savings Bank Deposit Accounts were 73.5 million in 2010, which increased to 243.0 in 2014 and 398.1 million in 2015 (RBI,2015).

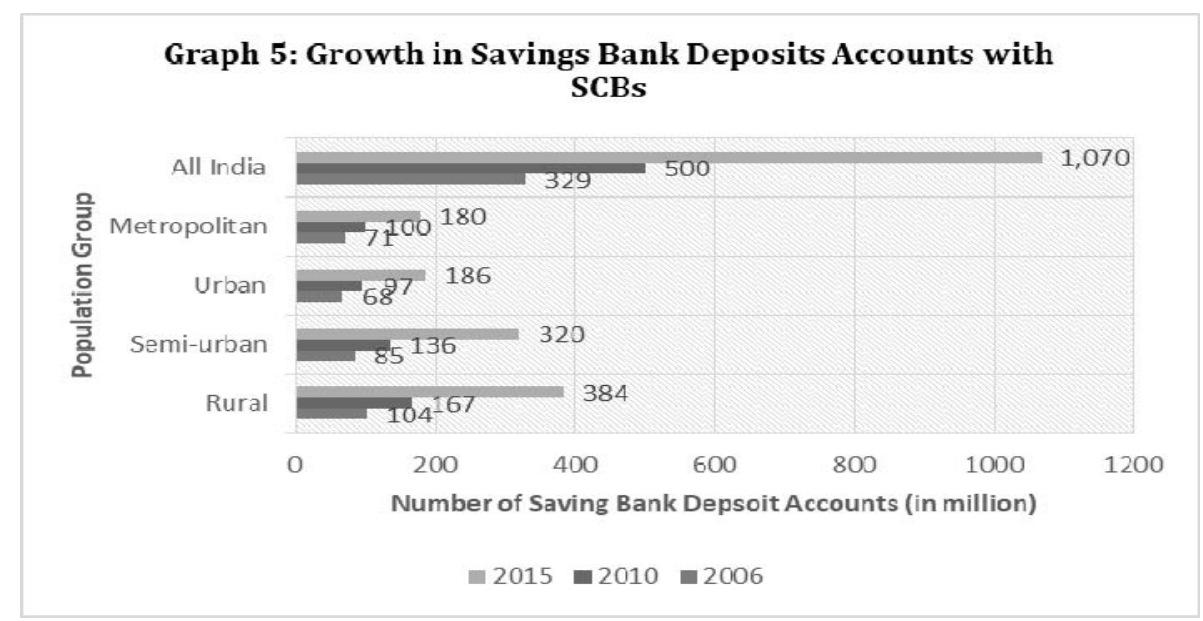

Source: RBI, Report of the Committee on Medium-term Path on Financial Inclusion 2015 
b) Electronically Know Your Customer (e-KYC): A paperless procedure for opening of accounts by customers having Aadhar cards.

c) Mobile Wallet: In 2012, the Reserve Bank of India sanctioned permission to telecommunication companies to offer Mobile Wallet facility to the people. As those telcos had a huge network of over 158,000 agents, of which 60 per cent were in remote areas, the mobile telephony and prepaid wallets were expected to encompass the unbanked people as well (RBI, 2013).

d) Immediate Payment Service (IMPS): Launched by NPCI in 2010 it offers an immediate, round the clock, inter-bank electronic fund transfer thru mobile phones, internet and ATMs. The client base who registered to mobile banking services was approximately 30 million by 2013. The number of Mobile Money Identifiers (MMID) issued were 4.7 million in 2010 increased to 63.2 million in 2014, and the number of transactions grew from 2001 to 5 million(RBI, 2014b).

e) Micro-ATMs: Micro-ATMs were installed at each 'Bank Mitra' location to facilitate immediate deposits and withdrawals. The micro-ATMs offer an online inter-operable and low-cost payment platform.

f) National Unified USSD Platform (NUUP): The Unstructured Supplementary Service Data (USSD) code and gateway, is device and operator independent; a solution for people who have basic phones and worked on GSM network. It facilitated balance inquiry, inter-bank fund transfer, mini statement besides others.

g) RuPay Debit Cards: RuPay card payment scheme launched in 2012, intended 'mass cardification'. It is offered a domestic, open-loop, multilateral system which facilitated electronic payments. Since its launch, the number of card-issuing banks have risen from around 60 to 238. In 2013 RuPay went online for e-commerce purpose and eventually finally become a credit card. The aim was to cover all the banks and about 12,000 online traders (RBI, 2013). RuPay cards were also issued to the188.6 million new bank accounts holder under PMJDY (mid-October 2015) to encourage the usage of bank accounts (Demirguc-Kunt et al., 2015; Kumar and Radcliffe, 2015; PMJDY, 2016).

h) RuPay Kisan Cards: NABARD inspired co-operative banks and RRBs to issue RuPay Kisan Cards for facilitating withdrawal/distribution of loans through PoS/ATM/micro ATMs using cards. Till 2013 close to 65,300 RuPay Kisan Cards were issued. Maharashtra and Karnataka were among the first states to roll out the scheme. There were 40 million farm accounts Kisan Credit Cards (KCC) in 2014. Besides, with the addition of 3.8 million small non-farm sector credits during 2013-14, there were 7.4 million non-farm accounts General Credit Cards (GCC) in 2014. Nearly 328 million transactions were carried out during 2013-14 as compared to 250 million during the preceding year (NABARD, Annual Report NABARD, 2013-14; RBI, 2014).

i) White Label ATMs (WLA): In 2012 the RBI allowed nonbanking entities to set up White Label ATMs (WLA) with an aim to enhance the spread of ATMs in remote areas where bank-owned ATMs were not working (RBI, 2014). The WLAs operate 4,370 ATMs, 60 per cent of that owned by Tata Communications Payment Solutions Private Limited.

j) Prepaid Payment Instruments: Licenses were issued to forty Prepaid Payment Instruments (PPIs) and ten payment aggregators. PPIs began with bill payments, railway ticketing, recharges and small transfers and gradually seized larger proportions of the customer wallet thru convenient and safe options for small disbursements and by making touchpoints for cash loading and cash out, thru Banking Correspondents, thus generating new category of service providers to assist in low margin, high-volume business (RBI, 2016; KPMG, 2016). In less than 18 months, PPIs contributed to more than $40 \%$ of all IMPS transactions and stimulating an eight-fold increase in prepaid transactions (PWC, 2015). Retail electronic payments grew from 167 million to 2,268 
million, while the volume of transaction grew about 100 times from about INR 500 billion to INR 50,000 billion (RBI, 2014).

k) Small Banks: In-principle approval was given to ten microlenders to set up small banks to give loans mainly to the unbanked, farmers, micro and small enterprises and unorganised sector which do not have access to funds. Brief profile of the entities who were given license to create small banks are given below (RBI,2015b; Indian Express, 2015):

i. Au Financiers (India) Ltd: Incorporated in 1996 as an NBFC, present across ten states in North India and provided vehicle loans and other loans to micro and small.

ii. Utkarsh Microfinance: Formed in 2009 and had a client base of 600,000 thru 271 branches, operated across eight states. 49 per cent rights held by Norwegian Microfinance Initiative, CDC and Lok Capital.

iii. $\quad$ RGVN (North East) Microfinance: Setup in 2008, had a network of 104 branches in 5 Northeastern states- Meghalaya, Assam, Sikkim, Arunachal Pradesh and Nagaland had around 220,000 borrowers.

iv. Disha Microfin: Established in 2009, offered credit to women in under-banked in remote areas in Madhya Pradesh, Gujarat, Rajasthan and Karnataka. In 2015, it had 71 branches across 39 districts and covered over 8,600 villages and had a total of 335,426 members and around 176,000 borrowers.

v. Capital Local Area Bank: It completed 15 years of operations in Jalandhar, Hoshiarpur in Punjab Ludhiana Kapurthala and Amritsar. It had 39 branches, 332,000 accounts and more than 80 per cent of its business is in remote areas.

vi. $\quad$ Equitas Holdings: Founded in 2007, operated 361 branches in 124 districts across seven states and had 2,292,000 customers.

vii. ESAF Microfinance: Largest MFI in Kerala that served 500,000 customers through 175 branches in Maharashtra, Kerala, Chhattisgarh and Jharkhand.

viii. Janalakshmi Financial: Largest urban MFI with 233 branches and a customer base of 2,300,000 and present in 151 cities across 17 states.

ix. Suryoday Microfinance: It operates in seven states, has 605,000 customers and a network of 164 branches and focusing only on female borrowers from deprived groups.

x. Ujjivan Financial: It is the fourth largest MFI in India which began operations in 2005. The company is spread across 24 states and Union Territories and serves over 2 million clients through a network of 423 branches.

l) Payment Banks: The Reserve Bank of India in August 2015 gave license to eleven nonbank entities to set-up 'payment banks'. The payment licenses have been granted to the security market entity, telecom companies, postal service provider, bottom of the pyramid players, payment service provider, technology companies, and NBFCs. Brief profile of entities who got granted a license to create payment banks (RBI, 2015a):

i. Aditya Birla Nuvo: Aditya Birla Group Company that owns Idea Cellular. As of June 2015 Idea Cellular had 162.08 million mobile and 37.16 million internet subscribers. Idea Cellular has an agreement with Axis Bank to offer mobile money transfer. During F.Y. 2014-15 Idea Cellular generated substantial revenues from its financial services business.

ii. $\quad$ Airtel M Commerce Services: Started 3 years ago. As in June 2015, Airtel had 234.11 million mobile and 82. 57 million internet subscribers. As on March 
2014, Airtel Money had 38 million transactions and 1.70 million active customers. Partnership with Kotak Mahindra Bank.

iii. Cholamandalam Distribution Services: Company has a network of 534 branches and more than 7,000 dealers across India. Has a customer base of over 750,000. 71 per cent of branches are in a remote region and end users are farmers.

iv. Department of Posts: Largest postal network in the world. Has a network of 154,856 post offices in India. Ninety per cent of post offices are in rural areas. 260,000 'dak sevakas' (Postmen) offers saving schemes and accepts public deposits.

v. Fino Pay Tech: Acquired Nokia Money in 2012, launched Alpha Payment Services in 2013. 450 FINO Money Marts and 15,000 trader distribution services. Had touched 80 million people for their banking needs.

vi. National Securities Depository: Handled a large volume of the transaction as a depository and held 14 million demat accounts.

vii. Tech Mahindra: Operated m-wallet is known as 'Mobo Money'. Launched NFC based payments for ICICI bank. Partnership with Mahindra Finance for the payment bank. Had a grid of about 100,000 outlets.

viii. Reliance Industries: Provided telephone and broadband services across all states, $90 \%$ of urban India and over 215,000 villages in India. Had 2,300 retail stores across 166 cities, connected to above 1 million customers per day, signed a joint venture with SBI which will hold $30 \%$ stake to set up payments banks.

ix. Dilip Shantilal Shanghvi: Founder of Sun Pharmaceuticals, partnered with Telenor Group and IDFC to provide banking services. Telenor group had an experience of being the world's leading mobile financial service provider.

x. Vijay Shekhar Sharma: Founder of Paytm, a mobile payment platform. Got license for prepaid wallets in 2013. Touched 100 million wallet users and 75 million transactions per month.

xi. Vodafone M Pesa: A two-year-old venture of tele company with 90,000 agents and had a client base of 3.6 million.

These entities who enjoyed an advantage over traditional banks in terms of robust infrastructure, enormous outreach, radical technology, and capacity to handle huge volumes of transactions, economies of scale and first mover advantage.

\section{DISCUSSION}

The study has shown that the government initiatives such as 'Pradhan Mantri Jan Dhan Yojana'(PMJDY), Pradhan Mantri Jeevan Jyoti Bima Yojana, 'Pradhan Mantri Bima Yojana' (PMBY), 'Pradhan Mantri' Micro Units Development and Refinance Agency Ltd, i.e. MUDRA Bank, Aadhar Enabled Payment Systems have created historic landmark. The government is also focusing on paying benefits of subsidies, pension scheme, remuneration under poverty alleviation programs and employment generation schemes such as Mahatma Gandhi National Rural Employment Guarantee Act (MNREGA) and such other twenty-five schemes directly into these accounts under Direct Benefits Transfer. This was bound to ensure that numerous accounts opened under such programs, remain active and witness 'movement' thus integrating access with usage. In India, the government benefits transfer market is worth USD 55 billion (where cash is being transferred to unbanked beneficiaries). The government's 'Digital India' initiative which aims at pan India fibre-optic network; provision of Wi-Fi services in major tourist centres and cities with substantial population; provision of internet access to village 
clusters; 'digital lockers'; universal phone and internet connectivity, will lead to digital empowerment, enhance demand for services and improve the governance. The government also wants to connect all the 250,000 village panchayats to a national optic fiber network, through 'BharatNet' which would expand the market for financial services. Branchless banking and mobile technology can make government-to-person (G2P) payments more accessible, efficient, safe and transparent as it will reduce leakage of funds, procedural delays and corruption and prove to be a great game changer.

Reserve Bank of India`s initiatives such as Mobile Wallet, Immediate Payment Service, microATMs, National Unified USSD Platform, RuPay Debit Cards, RuPay Kisan Cards, Kisan Credit Card, and White Label ATMs, aimed at creation of an efficient ecosystem for electronic/digital payments and ensure that the payment systems are accessible to one and all and efficient and that it boosts financial inclusion in a big way. These initiatives have facilitated millions of lowvalue high volume transactions through these platforms. Permission to forty prepaid payment instruments, ten aggregators, twelve small banks and eleven payment banks, resulted in a new revolution in the country's financial services sector. These new entrants are targeting the potential customer base in tier 2 cities, tier 3 cities and in rural India. New age technology companies, i.e., the 'fintech' have come forward to offer a variety of financial services across all different customer bases through digital platforms. They have already helped millions of people outside the formal banking circumference in accessing banking facilities, yet there is infinite untapped potential. India has conventionally been cash-dominated economy, with above 90 per cent of the volume of payments done in cash. However, with the introduction of the Payments and Settlement System, structural developments and regulatory reforms, trends hint at the ongoing transition towards the cashless financially inclusive economy, powered by the digital proposition.

Digital India holds the perspective to change the financial landscape; the way mobile transformed the face of connectivity. With its exceptional features such as ease of use, low cost, scalability and ubiquity, digital banking, when united with the innovative business model, an empowering ecosystem, can speed up the integration of the unbanked into the economic mainstream. The ongoing increased mobile penetration and use of mobile internet, clearly reflect at the potential of achieving total financial inclusion using digital platforms. The reports show that there were 453 million unique subscribers with sim connections in 2014, which is estimated to go up to 734 million in 2020 with a penetration rate of 54 per cent. The connections excluding M2M were 944 million in 2014 and is projected to go up to 1.3 billion in 2020 with a penetration rate of 94 per cent. The number of M2M connections are anticipated to reach 25 million by 2020 . There were 85 million mobile internet connections in 2010, which is expected to reach 592 million in 2020 with a penetration of 44 per cent. The data traffic is estimated to grow by a compound annual growth rate (CAGR) of 66 per cent over the period 2014-2019. There were 149 million smartphones in 2014, 185 million in mid-2015 and the anticipation is that this number will increase to 690 million by 2020. In 2010 the percentage of connections for a featured phone was 98 per cent, and this is expected to come down to 47 per cent in 2020, while the percentage of connections for smartphones which was 2 per cent in 2010 is projected to go up to 53 per cent in 2020.

The access to the internet in rural areas is growing by 58 per cent annually. Over the last three years, there were 11.2 billion electronic transactions done annually, 74 per cent of electronic transactions by debit and credit cards, prepaid instruments volume grew above 33 million, the shopping thru mobiles grew 800 per cent in 2013, and is expected to clock a CAGR of 150 per cent by 2016. (PwC \& ASSOCHAM, 2015; GSMA Intelligence, 2015). Looking at the ongoing trends and the future projections it seems necessary that financial intermediaries focus on "Digital financial inclusion" which broadly means using digital technology to reach unbanked and under-served people, with big basket of financial products and services, tailored to their needs, at an reasonable cost to the customer and is sustainable for the service-providers (GPFI White 
Paper, 2011; GPFI Issues Paper, 2014b; AFI , 2013).The traditional commercial banks, microfinance institutions and business correspondents need to leverage the penetration of mobile phone, smartphone, internet and emerging disruptive technologies. New business models, integrated strategies and partnerships need to be forged between banks, mobile network operators, technology companies and e-commerce companies for customer acquisition, customer retention, delivery of sustainable values to the new customer categories and for creating a remarkable customer experience by making available to them innovative customer service models.

As user-friendly technology is becoming popular among the low income and deprived groups, it opens up new horizons for the delivery of financial services at the doorstep of the customers. India Post, which has a network of 154,856 post offices, with nearly 90 per cent post offices in remote regions (India Post, 2016) needs to team up with mobile network operators and technology companies to deliver their services to the marginalised groups. The technology companies which offer innovative financial services such as mobile wallet and mobile money suffer from operating challenges and regulatory restrictions, which limit the volumes, so if such companies tie-up with financial companies it would solve a lot of issues. In India, not only urban areas but also countryside areas, are experiencing huge digital transformation. The financial intermediaries can think of working out partnership with Food Corporation of India, which has 504,715 fair price shops all over the country (Ministry of Consumer Affairs, Food and Public Distribution, 2016), and technology companies to set up shared Point-of-Sale (POS) equipment/ kiosks in fair price outlets, for allowing people to do basic banking transactions, using biometric identification and smart cards. This will speed up the process of financial inclusion, and will also bring down the cost of service. The Business Correspondent outlets / Customer Service Point (CSP) could be set up in the Village Panchayat Office, community health centres, 'kirana' shop, or any other public place.

\section{CONCLUSION}

To conclude, in the digital world, traditional discrepancies such as rich-poor, urban-rural, oldyoung, educated-uneducated, outdated-modern are becoming blurred. Today the issues that have become significant are seamless creation boundaries, user-friendly technology, universal mobile and internet connectivity, hassle-free transactions, increasing the use of regional linguistic in digital podia. As unbanked people increasingly gain access to mobile phone, smartphones and internets, it is essential that elementary financial services are offered at larger suitability and affordable cost using diversified digital platforms, to serve the poor customers better. The components of a financially inclusive ecosystem, i.e., reliable intermediaries, private players, innovative technology, payments infrastructure, banking, insurance, government and regulator, are already in place, yet better coordination is required at the market level, to enable a successful transition to a financially inclusive economy.

\section{REFERENCES}

Alliance for Financial Inclusion. (2013). Guideline Note on Indicators for Measuring Access and Usage, Mobile Financial Services Working Group, August 2013.

Brynjolfsson, E. \& Hitt, L. M. (2000). Beyond Computation: Information, Technology, Organizational Transformation and Business Performance. Journal of Economic Perspectives, 14 (4): 23-48.

CGAP, 2016. http://www.cgap.org/topics/digital-financial-services, retrieved on April 22, 2016.

Demirguc-Kunt, Asli et al. (2015). The Global Findex Database 2014. Measuring Financial Inclusion around the World. World Bank Group, Washington D.C.

Chakraborty, K. C. (2009). Technology, Financial Inclusion and the Role of Urban Cooperative Banks, RBI. 
Chakraborty K.C. (2011). Keynote address on Financial Inclusion, Mumbai, September 2011.

Das, P. K. (2010). The Up-Scaling of Technology to Build Inclusive Financial Systems in India. Journal of Education Administration and Policy Studies, 2(5): 67-70.

Digital India. (2016). Programme Pillars of 'Digital India' Campaign. Department of Electronics and Information Technology, Government of India. http://www.digitalindia.gov.in/content/programme-pillars, retrieved on April 29, 2016.

Gangopadhyay, S. (2009). How Can Technology Facilitate Financial Inclusion in India? A Discussion Paper. Review of Market Integration, 1(2): 223-256.

Global Envision. (2003). Lessons from the Field: ICTs in Microfinance. https://www.globalenvision.org/library/4/537, retrieved on April 29, 2016.

Government of India. (2008). "Committee on Financial Inclusion" (Chairman: Dr. C. Rangarajan).

GPFI. (2011). Global Standard-Setting Bodies and Financial Inclusion for the Poor toward Proportionate Standards and Guidance. http://www.microfinancegateway.org/library/global-standard setting-bodies-and-financialinclusion-poor-towards-proportionate-guidance,retrieved on April 29, 2016.

GPFI. (2014b). 2nd GPFI Conference on Standard-Setting Bodies and Financial Inclusion: Standard Setting in the Changing Landscape of Digital Financial Inclusion.

GSMA. (2015). The Mobile Economy India 2015, a report by GSMA Intelligence, pp1-56.

Hernandez, R. \& Mugica, Y. (2003). What Works: PRODEM FFP's Multilingual Smart ATMs for Microfinance. Innovative solutions for delivering financial services to rural Bolivia: World Resources Institute.

Hishigsuren, G. (2006). Information and Communication Technology and Microfinance: Options for Mongolia, $A D B$ Institute Discussion Paper No. 42.

Hughes, N. and Lonie S. (2007). M-PESA: Mobile Money for the -Unbanked\| Turning Cellphones into 24-Hour Tellers in Kenya. Innovations: Technology, Governance, Globalization, 2 (1-2): 63-81.

India Post. (2016). Post Office Network. http://www.indiapost.gov.in/Our_Network.aspx, retrieved on April 29, 2016.

Indian Express. (2015). http://indianexpress.com/article/india/india-others/new-licencessmall-banks-for-big-change/sthash.ulP1uLxs.dpuf, retrieved on April 24, 2016.

Kumar, K. \& Radcliffe, D. (2015). “Can India Achieve Universal Digital Financial Inclusion?" CGAP, 20 January 2015, http:// www.cgap.org/blog/can-india-achieve-universaldigitalfinancial-inclusion.

Kinyanjui, K. (2009). M-Pesa goes Global in Battle for Mobile Cash Transfer Pie. http://allafrica.com/stories/200910121448.html, retrieved on April 24, 2016.

KPMG. (2011). Role of digital banking in furthering financial inclusion, KPMG, 2016, 1-6.

Kravtsov, V. (2013). The evolution of bill payment kiosks in Eastern European countries. Kiosk Marketplace, http://www.kioskmarketplace.com/blogs/the-evolution-of-bill-paymentkiosks-in-eastern-europeancountries/, retrieved on April 9, 2016.

Mas, I. \& Morawczynski, 0. (2009). Designing Mobile Money Services: Lessons from M-PESA. Innovations: Technology, Governance, Globalization, 4 (2): 77-91.

Mendes, S. \& Alampay, E. (2007). The innovative use of mobile applications in the Philippines: Lessons for Africa. Sida Publications, Sida.

Ministry of Consumer Affairs, food and Public Distribution. (2016). Annual Report 2015-16, Department of Food and Public Distribution, Ministry of Consumer Affairs, food and Public Distribution, Government of India , pg 1-122.

Morawczynski, 0. (2008). Surviving in the dual system: How M-Pesa is Fostering Urban to Rural Remittances in a Kenyan Slum. HCC8, Pretoria, South Africa.

Morawczynski, 0. (2009). Examining the Usage and Impact of Transformational M-Banking in Kenya. Internationalization, Design and Global Development. N. Aykin (Ed), Springer Berlin/Heidelberg. 5623: 495-504. 
Morawczynski, O. \& Pickens, M. (2009). Poor People Using Mobile Financial Services: Observations on Customer Usage and Impact from M-Pesa. CGAP Brief.

Murphy, A. (2014). Beyond vouchers: Meeting growing demand for off-net P2P transfers. Findings based on the State of the Industry Report, GSMA.

Owens, J. (2015). Eight trends that will impact financial inclusion in 2015. AFI,

http://blogs.afiglobal.org/2015/01/20/eight-trends-that-will-impact-financial-inclusion-in2015/ retrieved on April 9, 2016.

Parada, M. \& Bull, G. (2014). In the Fast Lane: Innovations in Digital Finance. Washington, D.C.

Pénicaud \& Katakam. (2014). State of the Industry 2013: Mobile Financial Services for the Unbanked. GSMA.

Planning Commission. (2009). "Report on Financial Sector Reforms" (Chairman: Dr. Raghuram G. Rajan).

PMJDY. (2016). Progress-Report Pradhan Mantri Jan - Dhan Yojana as on April 20, 2016, http://www.pmjdy.gov.in/account, retrieved on April 29, 2016.

PPI. (2014). SBI Kiosk Banking - A Govt. push under Financial Inclusion. Pay Point India, http://blog.paypointindia.com/what-is-sbi-mini-banking/, retrieved on April 9, 2016.

PWC \& ASSOCHAM. (2015). "Logging into digital banking Creating access, transforming lives" A Report by PWC, ASSOCHAM, April 2015, 1-32.

Ravichandran, K. \& Alkhathlan, K. (2009). Financial Inclusion: A Path towards India's Future Economic Growth, March 2009.

Reserve Bank of India. (2012). Payment Systems in India: Vision 2012-15. Mumbai: RBI.

Reserve Bank of India (2012). RBI Bulletin, November. Mumbai: RBI.

Reserve Bank of India (2013). Annual Report 2012-13. Mumbai: RBI.

Reserve Bank of India (2014). Report of the Committee on Comprehensive Financial Services for Small Businesses and Low Income Households, Mumbai: RBI.

Reserve Bank of India. (2014). Reserve Bank of India`s Report on Financial Inclusion Progress: Banks and RRBS during 2013-14.

Reserve Bank of India. (2014b). Report of the Technical Committee on Mobile Banking. Mumbai: RBI.

Reserve Bank of India. https://www.rbi.org.in/Scripts/BS_PressReleaseDisplay.aspx?prid=34754, retrieved on April25, 2016.

Reserve Bank of India. (2015b). https://www.rbi.org.in/Scripts/BS_PressReleaseDisplay.aspx?prid=35010, retrieved on April $25,2016$.

Reserve Bank of India, (2016). https://rbidocs.rbi.org.in/rdocs/Publications/PDFs/ATH190315ENTPSP.PDF, retrieved on April 25, 2016.

Rolfe, A. (2015). Global mPOS installed base to quadruple to 54 million units. Payments Cards \& Mobile: http://www.paymentscardsandmobile.com/global-mpos-installed-base-toquadruple-to-54-millionunits/.

Shrader, L. (2013). Innovation in Person to Government Payments in the Philippines. CGAPBlog, http://www.cgap.org/blog/innovation-person-government-payments-philippines.

Ssewanyana, J. K. (2008). The Role of Free and Open Source Software in the Microfinance Sector in Uganda, IST-Africa 2008 Conference Proceedings. http://www.istafrica.org/conference, 2008.

Turaga, J. (2004). Opportunities and Challenges in India Kuch Apru Sock aur Kuch Jugaad: Crafting the MFI/IT Paradigm - The Indian Experience.

UIDAI. (2015). https://portal.uidai.gov.in/uidwebportal/dashboard, retrieved on 30 June, 2015.

Wishart, N. (2006). Micro-payment Systems and their Application to Mobile Networks: Examples of mobile enabled services in the Philippines. Infodev Publications, IDRC. 
World Bank. (2015). Financial Inclusion Data / Global Findex 2014, The World Bank Report 2015: http://datatopics.worldbank.org/financialinclusion/country/india, retrieved on April $29,2016$.

Article history: $\quad$ Received: February 9, 2018

Accepted: June 10, 2019 